Таким образом, данные глаголы объединены единой семантикой каузации контакта объектов и посессивных отношений. Каждая подгруппа глаголов данных ЛСГ отличается образом действия относительно объектов, т.е. соединять кого-либо с кемлибо, соединять что-либо с чем-либо, соединяться с кем-, чем-либо; приобщение независимого объекта и приобщение объекта, принадлежащего другому лицу (лицам).

1. Кильдибекова Т. А. Структура поля глаголов действия: Учебное пособие / Т. А. Кильдибекова. Уфа: Изд-во Башкирского госун-та, 1983. - 75 с.

2. Кузнецова Э. В. Русские глаголы «приобщения объекта» как функционально-семантический класс слов: автореф. дисс... докт. филол. наук / Э. В. Кузнецова. М., 1974. - 20 с.

3. Потапенко Т.А. Лексико-семантическая характеристика глаголов разрушительного воздействия на объект // Филологические науки. 1983. № 2. - С. 50-56.

4. Усманова М. Г. Функционально-семантическая классификация глаголов башкирского языка: дис. ... доктора филол. наук / М. Г. Усманова. - Уфа, 2002. - 429 с.

5. Чертыкова М Д. Глаголы со значением психической деятельности в хакасском языке: дис. ... доктора филол. наук / М. Д. Чертыкова. - Абакан, 2016. - С 44.

\title{
Kolyada N.A. \\ The importance of developing intercultural communication skills in teaching foreign languages
}

Southern Federal University

(Russia, Rostov-on-Don)

doi: $10.18411 / \mathrm{lj}-08-2021-100$

\section{Abstract}

The article considers teaching a foreign language as a means of everyday communication with native speakers of another culture. Special attention is paid to crosscultural learning, which contributes to the achievement of cross-cultural communication. The article offers opportunities for developing the abilities and skills of cross-cultural communication with the involvement of the material of linguistic and cultural content, provides examples of exercises for the development and consolidation of cross-cultural communication skills, aimed at the ability to interpret the existing various models of perception of the world, to relate other cultural customs and mores with their behavioral norms.

Keywords: foreign language communication, the concept of communicative learning, linguistic and foreign studies material, culture and language.

\section{Аннотация}

Рассматривается преподавание иностранного языка как средства повседневного общения с носителями другой культуры. Особое внимание уделяется межкультурному обучению, способствующему достижению межкультурной коммуникации. Предлагаются возможности для развития способностей и навыков межкультурного общения с привлечением материала лингвострановедческого содержания, приводятся примеры упражнений для развития и закрепления навыков межкультурного общения, направленные на умение интерпретировать существующие различные модели восприятия мира, соотносить иные культурные обычаи и нравы со своими поведенческими нормами.

Ключевые слова: иноязычная коммуникация, концепция коммуникативного обучения, лингвострановедческий материал, культура и язык.

The Russian methodology of teaching foreign languages is constantly improving and offers many recommendations and guidelines for achieving the goals set. For a long time, the 
main focus in teaching foreign languages in higher educational institutions was professionally oriented. The purpose of such training was, first of all, the development of abilities and readiness for foreign language speech activity for business intercultural communication, participation in international conferences, symposiums. It was assumed that a graduate of the university should be able to conduct a dialogue, discussions on scientific problems within the framework of his specialization $[1,2,4,8]$.

However, life dictates its own requirements, and it is already becoming insufficient to speak only a professional language. An important factor in this case is the formation of foreign-language communicative competence in intercultural communication. In other words, teaching a foreign language should be aimed at mastering a foreign language as a means of everyday communication with native speakers of another culture, which in turn requires the development of the student's ability to cross-cultural communication.

The term "communication", which appeared at the beginning of the XX century and is considered in the scientific literature to a greater extent by scientists - philosophers, cultural scientists, was reduced to the concept of information exchange within the sign system of both verbal and non-verbal means of communication.

It should be noted that the communicative and most important, primary function in the process of human activity is still performed by language, which helps a person to form an idea of the world around him.

It is the communication of people with the help of language that is considered in science to be language communication, and each case of such communication is called an act of communication (KA).

In the process of teaching foreign languages, theorists and practitioners develop new methods, while putting the concept of communicative learning more and more at the forefront. The communicative basis in the study of a foreign language becomes a normative requirement for the organization of successful training based on tasks of a communicative nature, that is, communication, which is equated with intercultural communication [5].

The relevance in this regard lies in the importance of the so-called cross-cultural approach, which is addressed by many Russian researchers. The above-mentioned approach is aimed at the formation and development of cross-cultural competence for interaction with representatives of different cultures, countries, and societies.

When learning a foreign language, the student is certainly faced with the culture of a particular people, the language of which he is studying. The expansion of cross-cultural contacts, the information flow, as a special exchange of information and a way of communication, forces us to change the idea of cross-cultural communication [3]. In other words, to remove difficulties on this issue, it is necessary to study a foreign language in inseparable unity with the world and culture of the people, the language being studied, since intercultural communication is communication between people from different cultures [6].

The main components of familiarization with the culture of another people include such as traditions, customs, holidays; norms of everyday communication, rules of behavior in public places, forms of greeting, farewell; acquaintance with the cultural heritage of the people, that is, everything that makes up a kind of national-specific characteristic of the people. In this regard, special attention of researchers on this issue is paid to the problem of integrating the components of the culture of the people of the studied language into the teaching of a foreign language. The goal of the communicative methodology is not just to teach a foreign language, but to introduce it to a foreign language culture, which includes a number of aspects, such as: cognitive, educational, developing, educational [7]. The process of teaching foreign languages has recently been considered as the study of language and culture. In foreign language classes, they try not only to teach students how to master the skills and how to ask questions, but also how to actively participate in the conversation, expanding their questions-questions; the ability to build their own arguments on a particular 
issue of the conversation, the ability to contrast their own information with the information of the interlocutor.

Taking into account the fact that teaching a foreign language takes place in the socalled "Artificial Environment", methodologists and practitioners develop a set of exercises of a communicative nature in order to achieve intercultural communication. An example of this is the exercises in the classroom when learning a foreign language on the topic "Folk traditions" (author's development):

No. 1

a. Get acquainted with such a tradition as "Baptism".

b. Express your opinion about the significance of baptism in a person's life. Does this tradition play any role for a happy life or does it have no meaning.

at all? Talk about the topic "Is there such a tradition in your country? Are you baptized? Why? Are there differences in this tradition in your country in the country of the language you are studying? Which ones?

No. 2

a. Get acquainted with such a tradition as "Wedding. Betrothal".

b. What traditions and customs exist in your country?

c. Express your opinion about such a tradition as "Betrothal". Is there such a tradition in your country?

\# 3 On the basis of the proposed text "What do foreigners say about the culture of your country", express your opinion on some questions:

a) How would you describe your country to a foreigner?

b) How do you perceive the culinary delights of other countries?

c) How do you meet your guests at home? What do you offer them? Are there any traditions of receiving guests?

Teaching a foreign language involves instilling in students not only knowledge of the lexical and grammatical material of the language being studied, not only the ability to construct questions and answers, but also to convey information about the culture of the country of the language being studied, about the cultural heritage, which is a contribution to the world treasury.

Thus, the linguistic and country studies work of a foreign language teacher, the country studies aspect is not an addition to the educational process, but an integral part of it for the exchange of oral and written information, expanding the horizons, the boundaries of perception and perception of the world.

The exercises should be aimed at business communication in the correct manner of greeting, addressing strangers, to representatives of companies with which students will cooperate in the future or take part in conferences, symposiums and other official events. At the same time, it is necessary to introduce students to the etiquette of greeting and saying goodbye, writing business letters.

So, for example, in Germany, it is customary to address not by first name, patronymic, as in Russia, but by calling an academic degree or scientific title, Mr. (Herr) or mrs. (Frau) + last name.

When communicating by e-mail, you need to know how to write a letter, how to address it, and how to say goodbye, since each country has certain rules that should be followed. It is also important to know that any email must be answered, even if the answer is negative.

Students should also be introduced to the norms of everyday life. For example, on questions about how and when to come to visit with a private invitation or for an official reception, for a dinner party that you can not be late for, or for a party. Not a little important factor is the question of the location of guests at the table. In some countries, it is customary to place cards on the table with the name, surname or title of guests. On this occasion, a number of exercises can be proposed regarding the statement on this issue. For example. why does this make sense when receiving guests and what is the purpose of this method? 
At the same time, it is necessary to inform the students about how and in what form flowers should be given: if, for example, in some countries the number of flowers is even or odd, but in your country this does not matter.

The question of how gifts are presented is always of interest. At the same time, exercises can be offered to express your opinion on such issues as:

- do you write your wishes when giving a book in the book itself, or should you attach a card with your wishes,

- do you agree that the gift should be opened in the presence of guests,

- whether the criteria for choosing a gift are essential for you.

Recently, many university graduates prefer to work abroad. The teacher should raise the question of what requirements can be presented during the interview. In some countries, this is not particularly paid attention to. But in some countries, not a small role in the interview is played by the following:

— appearance of the applicant for the job.

- punctuality.

- awareness of the company in which the applicant would like to get a job.

- the manner of behavior and conversation.

The application for a job can be made either in writing or orally, for example, by phone. Therefore. In the classroom, you should offer exercises for training telephone conversations: addressing, presenting the problem and saying goodbye.

All of the above points to the urgent need not only for the linguistic and cultural aspect of teaching foreign languages, but also for such a type of work in foreign language classes as a business foreign language in the field of professional communication.

\section{$* * *$}

1. Burlakov M.A. What should be the system of exercises? // Foreign languages at school. - 1987. - No.4. p. 45-48.

2. Vereshchagin E.M., Kostomarov V.G. Language and culture. M: Indrik, 2005 - - 1040 p. ISBN: 5-85759289-5.

3. Zakharova, E.A. Communicative teaching of a foreign language and its practical significance / E.A. Zakharova. - Text: direct / / Young scientist. — 2016. — № 5 (109). — Pp. 676-679. - URL: https://moluch.ru/archive/109/26246/ (accessed: 27.07.2021).

4. Kolyada N.A. Language-the principle of communication in teaching foreign languages / N.A. Kolyada / / Actual issues of philology and methods of teaching foreign languages. Interuniversity collection of scientific articles. Issue 8. - Rostov-on-Don: Rostov Institute of Foreign Languages. - 2010. - pp. 91-98. ISBN 5-85216-064-9.

5. The concept of intercultural communication. [Electronic resource] https://studme.org/90288/kulturologiya/ponyatie_mezhkulturnoy_kommunikatsii

6. Psychology of communication and culture. [Electronic resource] https://studopedia.ru/4_34512_psihologiya-obshcheniya-i-kultura.html

7. Comparative characteristics of methods of teaching English. [Electronic resource] https://knowledge.allbest.ru/languages/3c0a65635a2ac68b4c53a88521306c27_0.html

8. Samovar L., Porter R. Intercultural Communication: a Reader. 7, hed. Belmont: Wadsworth, 1994.

Shabasheva E., Ignatovich Y.

Conceptual blending in the formation of English and Russian colour idioms based on physiological and psychological influence

Immanuel Kant Baltic Federal University

(Russia, Kaliningrad)

doi: 10.18411/lj-08-2021-101

Abstract

In this paper the authors investigate the problem of value meaning formation in Russian and English colour idioms based on the theory of conceptual blending. Special 